\title{
STRENGTHENING CHARACTER EDUCATION BASED ON GOLDEN HABITS AT SMP MUHAMMADIYAH 1 DEPOK YOGYAKARTA
}

\author{
Arham Junaidi Firman \\ State Islamic University (UIN) Sunan Kalijaga Yogyakarta \\ Email: arhamjf@yahoo.com \\ Nur Hidayat \\ State Islamic University (UIN) Sunan Kalijaga Yogyakarta \\ Email: bos_hidayat@yahoo.com
}

\begin{abstract}
This research is motivated by a deterioration in character values characterized by frequent psychological or moral violence. This type of research is qualitative research with a descriptive approach. This research was conducted in SMP Muhammadiyah 1 Depok Yogyakarta. The data gathered from the principal, assistant principal of curriculum, assistant principals of students s affairs, and five teachers of Ismuba. The results of this study showed: firstly, the planning of the strengthening golden habits character education was done through socialization to education practitioners, elaboration into the vision, mission, and goals of the school, designing and formulating activities of the strengthening character education through habituation. Secondly, the strengthening of golden habits character education was carried out through tahfidz, mufrodat, and mahfudzat in Arabic, English, and Javanese; the worship practice was decided by the tarjih assembly. Thirdly, evaluation of character strengthening based on golden habits was carried out with an evaluation pattern through three-scale scoring techniques, spontaneously, analysis of program implementation through work meetings, monitoring changes in student behavior, and reports on student character behavior and scoring.
\end{abstract}

Abstrak: Penelitian ini dilatarbelakangi karena terjadinya kemerosotan pada nilai-nilai karakter yang ditandai dengan seringnya dijumpai tindak kekerasan psikis ataupun moral. Jenis penelitian ini adalah penelitian kualitatif dengan pendekatan deskriptif. Penelitian ini dilakukan di SMP Muhammadiyah 1 Depok Yogyakarta. Subyek untuk perolehan sumber data, yaitu kepala sekolah, waka kurikulum, waka kesiswaan dan 5 guru Ismuba. Hasil penelitian ini menunjukkan, yaitu: pertama, perencanaan penguatan pendidikan karakter berbasis golden habits dilakukan dengan pola sosialisasi kepada praktisi pendidikan, penjabaran ke dalam visi, misi dan tujuan sekolah, mendesain dan 
merumuskan kegiatan penguatan pendidikan karakter melalui pembiasaan. Kedua, pelaksanaan penguatan pendidikan karakter berbasis golden habits dilakukan dengan pola kegiatan hafalan ayat-ayat Al-Qur'an pilihan di luar juz 30, hafalan pilihan dan wajib juz 30, mufrodat dan mahfudzat bahasa Arab, Inggris dan Jawa, amalan ibadah harian yang diputuskan oleh majelis tarjih. Ketiga, evaluasi penguatan pendidikan karakter berbasis golden habits dilakukan dengan pola lembar evaluasi melalui teknik penskoran skala tiga, secara spontan, analisa pelaksanaan program melalui rapat kerja, pengamatan perubahan tingkah laku peserta didik, laporan pengamatan perilaku karakter peserta didik dan penskoran.

Keywords: strengthening character education; golden habits; SMP Muhammadiyah 1 Depok Yogyakarta

\section{INTRODUCTION}

Allah created humans in the best structure among His other creatures. The human structure consists of physical (physiological) and spiritual (psychological) elements and is equipped with a set of basic abilities to develop for good or bad, ${ }^{1}$ as Allah says in QS Al-Balad verse 10, "and we have shown him two ways." 2 The two paths refer to virtue and evil ways. In developing their potential, humans and education are two things that cannot be separated. Humans need the education to develop self-actualization. On the other hand, the existence of education depends on human existence itself. It means that education is due to the existence of humans, so it can be said that education began to exist when the existence of man himself. ${ }^{3}$

The complexity of the education system in Indonesia requires teachers to be teachers and show their capacity as a teacher who sincerely devotes energy and ability to educate their students. Thus, an education built on gentleness produces better results than those built on violence and intimidation. ${ }^{4}$

In this current contextualization, it shows that education is experiencing quite severe tests and challenges. One of these is the decline in character values marked by frequent occurrences of psychological or moral violence against

1 Arham Junaidi Firman, "Paradigma Hasan Langgulung Tentang Konsep Fitrah Dalam Pendidikan Islam,” Jurnal Uhamka 8, no. 2 (2017), 123-43.

2 Departemen Agama, Al-Hikmah; Al-Quran Dan Terjemahannya (Bandung: Diponegoro, 2008), 594.

3 Arham Junaidi Firman, "Menyoal Akses Pendidikan Bagi Kelompok Marginal Dalam Mewujudkan Kesetaraan Dalam Pendidikan," dalam PROSIDING SEMINAR NASIONAL "TELLU CAPPA" (Kontribusi Untuk Pendidikan, Genetika Emas Indonesia), (Makassar: Badan Penerbit Universitas Negeri Makassar, 2017), 109-116.

${ }^{4}$ Muhammad Nabil Kazhim, Sukses Mendidik Anak Tanpa Kekerasan (Solo: Samudera, 2011): 42. 
teachers and students who are its practitioners. Data from the Indonesian Child Protection Commission (KPAI) in 2018 noted that $84 \%$ of students had experienced violence at school, $40 \%$ of students aged 13-15 reported having experienced physical violence by peers, $75 \%$ of students admitted to having committed violence at school and $50 \%$ of children report experiencing bullying at school. The violence was not only committed by students but also by teachers and school officials. ${ }^{5}$

The real impact of this problem is a decrease in appreciation and respect for oneself, others who are older (parents and teachers), the waning of love for others and the universe so that this is no longer seen as good and true values in human life. ${ }^{6}$ Also, a piece of the fact above raises the question, what is wrong with the world of National Education? If this is allowed to do so, then there will be no systemic effort to prevent it, so that the nation will suffer and lose due to rampant violence that occurs in education.

The government has made various efforts. One of which is by making schools a means of strengthening character education. However, efforts to create a character education model have not achieved well as mandated in Pancasila, the 1945 Constitution, and Law no. 20 of 2003 concerning the National Education System. It indicates that the program is still not optimal in realizing schools as a safe, comfortable, and character formers' place. Schools should be the basis for developing and strengthening character education to carry out their functions properly.

Therefore, the researchers view that one way of realizing a character education model is through the movement to strengthen character education in schools as mandated in Presidential Decree No. 87 of 2017 concerning the Movement of Strengthening Character Education. The movement to strengthen character education is an educational movement under the responsibility of the education unit to strengthen the character of students through the harmonization of heart, feeling, thinking, and sports with involvement and cooperation between educational units, families, and communities as part of the National Movement of Mental Revolution (GNRM).?

SMP Muhammadiyah 1 Depok Yogyakarta is one of the schools that has carried out a movement to strengthen character education. Character education at SMP Muhammadiyah 1 Depok Yogyakarta has been implemented since

5 Alfan Hilmi, "Hari Pendidikan, KPAI: 84 Persen Siswa Alami Kekerasan Di Sekolah," 2018, https://nasional.tempo.co/read/1084922/hari-pendidikan-kpai-84-persen-siswa-alamikekerasan-di-sekolah, diakses tanggal 15 Juni 2018.

${ }^{6}$ Nur Hidayat, Pendidikan Karakter Di Pesantren; Model Keteladanan Dan Pembiasaan (Yogyakarta: Calpulis, 2018), 2.

7 Presiden RI, Peraturan Presiden RI No. 87 Tahun 2017 Tentang Penguatan Pendidikan Karakter (Jakarta: Presiden RI, 2017), 2. 
2010 by applying 19 character values before the current government. In 2016, with a program of strengthening character education by the government, SMP Muhammadiyah 1 Depok Yogyakarta volunteered and was appointed by the government as a pilot school in character education. So, the implementation of character education at SMP Muhammadiyah 1 Depok Yogyakarta is more real and comprehensive with parameters. It is strengthened by Presidential Regulation No. 87 of 2017 concerning the Movement of Strengthening Character Education.

The implementation of strengthening character education at SMP Muhammadiyah 1 Depok Yogyakarta aims to create students with strong Islamic character, which will be their culture in daily lives. In 2011, SMP Muhammadiyah 1 Depok Yogyakarta developed the Al-Islam Kemuhammadiyahan Arabic and English Language (ISMUBARIS) program as a character education strengthening program. The ISMUBARIS program was implemented based on a golden habit. It included memorizing selected Qur'anic verses outside juz 30, memorizing juz 30, mufrodat, mahfudzat Arabic, English, and Javanese, as well as daily worship practices decided by the tarjih council. In 2018, SMP Muhammadiyah 1 Depok Yogyakarta was equipped with the inculcation of programmed character values from the Ministry of Education and Culture through the Strengthening Character Education (PPK) program.

Based on the explanation, the government stipulated SMP Muhammadiyah 1 Depok Y ogyakarta as a pilot school to strengthen character education. Therefore, researchers are interested in studying it. Based on the statement, this research focuses on "how is the pattern of strengthening character education based on golden habits in SMP Muhammadiyah 1 Depok Yogyakarta?".

There are several previous literature reviews related to the object of this research. First, Endang Komara with the title "Penguatan Pendidikan Karakter dan Pembelajaran Abad 21." Second, Asep Dahliana with the title "Penguatan Pendidikan Karakter Melalui Kegiatan Ekstrakurikuler di Sekolah." "Third, Sutiyana Fachruddin, et al., with the title "Communication Model BasedCharacte $r$ Strengthening Through Language Politeness As Prevention Of Bullying Toward Junior High School (Case Study At SMPN 20 Kota Kendari).”10

${ }^{8}$ Endang Komara, "Penguatan Pendidikan Karakter Dan Pembelajaran Abad 21," SIPATAHOENAN: South-East Asian Journal for Youth, Sports \& Health Education 4, no. 1 (2018): 17-26, www.journals.mindamas.com/index.php/sipatahoenan.

9 Asep Dahliyana, "Penguatan Pendidikan Karakter Melalui Kegiatan Ekstrakurikuler Di Sekolah,” Sosio Religi: Jurnal Kajian Pendidikan Umum 15, no. 1 (2017).

${ }^{10}$ Sutiyana Fachruddin et al., "Communication Model Based-Character Strengthening Through La nguage Politeness As Prevention Of Bullying Toward Junior High School (Case Study At S mpn 20 Kota Kendari)” 7, no. 5 (2017): 68-75, https://doi.org/10.9790/73880705066875. 
Fourth, Dwi Hastuti, et al., with the title "An Integration of Family and School on Strengthening the Character of Teenager in Indonesia: It's a Must." ${ }^{11}$ Fifth, Salsabilah with the title "Pendidikan Karakter Islami Berbasis Nilai-Nilai Kearifan Lokal (Penelitian di SDN 12 Ciseureuh Kahuripan Pajajaran Purwakarta)."12 Sixth, Wilis Werdiningsih with the title "Pengembangan Nilai Karakter Siswa dalam Pendidikan Agama Islam dan Budi Pekerti Jenjang SMP Pada Kurikulum 2013"13 Seventh, H.A. Rodli Makmun with the title "Pembentukan Karakter Berbasis Pendidikan Pesantren: Studi di Pondok Pesantren Tradisional dan Modern di Kabupaten Ponorogo."14

This study will strengthen some of the previous literature reviews that have been described. Besides, it also shows that there are differences between the earlier studies and the conducted research. Thus, they can be used as reference material to complement the object of study. This study aims to uncover and explore indepth the patterns of strengthening character education based on golden habits in planning, implementation, and evaluation at SMP Muhammadiyah 1 Depok Yogyakarta.

\section{RESEARCH METHOD}

This research employed qualitative research using a descriptive approach. It was because the experiences that exist in the world of education in strengthening character education can be said to be always different. Of course, the thing that makes it different is not only the reinforcement but also more about how the school prepares itself for this. This research was conducted in 3 months from December 2018 to February 2019 at SMP Muhammadiyah 1 Depok Yogyakarta. The subjects of the data sources were eight people. They were the principal, assistant p rincipal of curriculum, assistant principal of students affairs, and 5 Ismuba te achers at SMP Muhammadiyah 1 Depok Yogyakarta. The data collection techniques used were observation, interviews, and documentation. The data analysis was done based on the model of Miles and Huberman. They were data reduction, data display, and data verification.

${ }^{11}$ Alfiasari Alfiasari, Dwi Hastuti, and Sarwititi Sarwoprasodjo, "An Integration of Family and School on Strengthening the Character of Teenager in Indonesia: It's a Must," Journal of Child Development Studies 1, no. 01 (2016): 13, https://doi.org/10.29244/jcds.1.01.13-26.

${ }^{12}$ Salsabilah, "Pendidikan Karakter Islami Berbasis Nilai-Nilai Kearifan Lokal (Penelitian Di SDN 12 Ciseureuh Kahuripan Pajajaran Purwakarta),” Cendekia 17, no. 2 (2019): 269-84.

${ }^{13}$ Wilis Werdiningsih, "Pengembangan Nilai Karakter Siswa dalam Pendidikan Agama Islam dan Budi Pekerti Pada Kurikulum 2013," Cendekia: Journal of Education and Society 15, no. 2 (2018): 283, https://doi.org/10.21154/cendekia.v15i2.1123.

${ }^{14}$ H.A. Rodli Makmun, "Pembentukan Karakter Berbasis Pendidikan Pesantren: Studi Di Pondok Pesantren Tradisional Dan Modern Di Kabupaten Ponorogo," Cendekia: Jurnal Kependidikan Dan Kemasyarakatan 12, no. 2 (2016): 211, https://doi.org/10.21154/cendekia. v12i2.226. 


\section{THEORETICAL FRAMEWORK}

Character education instills character values for school members with knowledge, awareness, or willingness and action to carry out these values. The purpose of character education is to improve the quality and outcomes of education in schools that lead to the complete, integrated, a nd balanced achievement of character building and noble morals in stude $\mathrm{n}$ ts according to graduate competency standards. ${ }^{15}$

Meanwhile, the strengthening of character education in schools was played by the Minister of Education and Culture Muhajir Efendi after being inaugurated as Minister of Education and Culture in 2016. Strengthening the nation's character is one of the main tasks and as a form of implementation of tasks that have been directed by President Joko Widodo through the National Movement for the Mental Revolution ( GNRM). Through the movement to strengthen character education, the government hopes that there is a character development into a spirit or soul inherent in the implementation of education and encourages character in the form of synergy between heart, sports, taste, and initiative. ${ }^{16}$

The concept and design of strengthening character education emerge and become an important issue in today's education world. It departs from the view that it is necessary to restructure and reposition the character as the spirit of the deepest dimension of national education side by side with the intellectuality reflected incompetence. With a strong and tough character and competence through a good education, various new needs, challenges, and demands can be met or overcome. Therefore, in addition to intellectual development, strengthening students' character is very important in the Indonesian national education system. It is said so because basically, education aims to develop the intellectual potentials and character of students. ${ }^{17}$

Five main character values are mutually sustainable in forming a network of character values: religious, nationalist, cooperation, independence, and integrity. To instill five main values and create a character education strengthening program in schools, it is necessary to collaborate with the principal and teachers to actualize them in learning activities. The principal's task is to design school culture to become the hallmark and excellence of the school, while the teacher's

15 Putri Rachmadyanti, "Penguatan Pendidikan Karakter Bagi Siswa Sekolah Dasar Melalui Kearifan Lokal,” Jurnal Pendidikan Sekolah Dasar, 3, no. 2 (2017): 201-214.

${ }^{16}$ Hendro Widodo, "Penguatan Pendidikan Karakter Di Sd Muhammadiyah Macanan Sleman Yogyakarta,” Lentera Pendidikan 22, no. 1 (2019): 40-51.

${ }^{17}$ Yetri Hasan and Rijal Firdaos, "Penguatan Pendidikan Karakter Berbasis Masyarakat Pada Sekolah Menengah Pertama Negeri (SMPN) Di Kabupaten Tulang Bawang Provinsi Lampung," Al-Tadzkiyyah: Jurnal Pendidikan Islam 8, no. 2 (2017): 267, https://doi.org/10.24042/atjpi. v8i2.2131. 
job is to integrate the five main character values in classroom learning and manage class management so that character education strengthening programs can be realized. ${ }^{18}$

Observing this, one of the critical success factors in carrying out a movement to strengthen character education is through refraction. Habit is one of the most important educational methods, especially for students, because they have not realized what is good and bad in a moral sense. Students also do not have obligations that must be done like adults. So it needs to be familiarized with certain attitudes skills, skills, and mindsets. Students need to be accustomed to something good because it will change all good qualities into habits so that the soul can fulfill the habit without too much effort, without losing a lot of energy, and without finding much difficulty. ${ }^{19}$

Students who already have certain habits will be able to do it easily and happily. Anything that has become a habit at a young age is difficult to change and persists into old age. Changing it requires serious therapy and self-control. This habit encourages and provides space for students to theories that foster direct application so that heavy theories become light for students if they are often implemented. ${ }^{20}$ Teachers have an important role in implementing this habituation method, which requires support from their students. If students do not have the interest or motivation to follow this habituation, this method will certainly only be a theory. Motivation is needed in supporting this implementation so that the religious spirit and awareness of students can emerge.

Besides, to achieve the goal of character education according to the target, it is necessary to have a management program for strengthening character education in schools. As described by Agus Wibowo, management of strengthening character education is a process of planning, implementation, and evaluation to achieve effective and efficient goals that are integrated and closely related to school management or management. ${ }^{21}$

\section{RESEARCH FINDINGS AND DISCUSSION \\ Planning for Strengthening Character Education based on Golden Habits at SMP Muhammadiyah 1 Depok Yogyakarta}

Based on the research results, planning in the program to strengthen character education based on golden habits was departed from the understanding of the

${ }^{18}$ Atik Maisaro, "Manajemen Program Penguatan Pendidikan Karakter Di Sekolah Dasar," JAMP: Jurnal Administrasi Dan Manajemen Pendidikan 1, no. 3 (2018): 302-312.

${ }^{19}$ Abuddin Nata, Filsafat Pendidikan Islam (Jakarta: Logos Wacana Ilmu, 1997), 10.

${ }^{20}$ Ulil Amri Syafri, Pendidikan Karakter Berbasis Al-Qur'an (Jakarta: Rajawali Pers, 2012), 140.

${ }^{21}$ Agus Wibowo, Manajemen Pendidikan Karakter Di Sekolah (Yogyakarta: Pustaka Pelajar, 2013), 137. 
implementers. They were the principal, representatives, and teachers of the movement to strengthen character education. An implementer can't carry out a plan if they do not understand what will be planned. Planning is used to anticipate unexpected possibilities.

In the context of the character education strengthening program, planning is very important to be carried out in the Mental Revolution National Movement's success as the nawacita of the RPJM of the Joko Widodo administration. The movement to strengthen character education is not something new. Long before President Joko Widodo went through the spirit of a mental revolution, it was broken down into strengthening character education; SMP Muhammadiyah has implemented character education because character education is the main axis of education that covers heart, thought, feeling, and sports. Character education at SMP Muhammadiyah 1 Depok Yogyakarta has been running with 19 character values before the current government era. However, the implementation of the 19 character values is limited to administrative, not comprehensive, not comprehensive, and not systemic so that students could not live in real life of students as the results of interviews conducted with Mr. Abdulah Mukti. The government made a breakthrough to strengthen character education based on school culture, class basis, and community basis.

To achieve success, every party in the school must cooperate and be committed to streng thening characte $r$ education programs; one way is by conducting socialization. The school conducts outreach to education practitioners (teachers, school committees, parents/guardians of students, students, communities, and stakeholders) relevant to the character education strengthening program. The socialization process is carried out through various activities, including through parenting on each new teaching and educational activities in accordance with the stages of development of students.

After carrying out socialization, parenting, and educational activities, the next step is to integrate the strengthening of character education into the school's vision and mission carried out by the KDP team through coordination with the vision and mission drafting team, including the education and education council, then conveyed to the Founding and Development Team of SMP Muhammadiyah 1 Depok Yogyakarta. Based on the documentation results, the vision of SMP Muhammadiyah 1 Depok Yogyakarta is to have noble character, independence, creativity, achievement, and a global perspective. Meanwhile, the school mission related to the strengthening of character education movement can be seen in the first point, namely the realization of the student's personality identity with Islamic and Muhammadiyah characteristics.

The spirit of change, innovation, and creativity in strengthening character carried out by SMP Muhammadiyah 1 Depok Yogyakarta is supported by the 
school-b a sed management im plemented. This school can rise and develop rapidly. In terms of innovation and creativity, as a school with a vision of being noble, independent, creative, achievers, and has a global perspective, it is always pursued optimally. Strengthening character education at SMP Muhammadiyah 1 Depok Yogyakarta is consistently pursued systematically, simultaneously, and comprehensively by prioritizing habituation, which is actualized in the pulse of school life. SMP Muhammadiyah 1 Depok Yogyakarta in 2010-2013 collaborated with the Living Values Education Program (LVEP).

In the next stage, strengthening character education is carried out by designing and formulating activities to strengthen character education through habituation by integrating the five main values of mutually sustainable character as found in the theoretical discussion. Therefore, strengthening character education at SMP Muhammadiyah 1 Depok Yogyakarta is carried out through ISMUBARIS activities as golden habits in character education.

It is based on a change in the mindset of characte $r$ education among teachers, students, and parents so that students have golden habits and have a strong Islamic character and make it as a culture. So that SMP Muhammadiyah 1 Depok Yogyakarta in 2011 developed the ISMUBARIS program, which consists of memorizing selected Qur'anic verses outside of juz 30, memorizing juz 30, mufradat and mahfudzat Arabic, English, and Javanese, as well as daily worship practices. This program was run regularly (everyday) for 20 minutes.

In the beginning, the ISMUBARIS program was only limited to a hidden curriculum, but due to the high attention of students and parents and a positive response, this program was patented and implemented from 2013 until now on every Tuesday-Friday with a duration of 20 minutes. The assistant was all teachers who met the qualifications. The recruitment was prioritized for multitalented teachers. This program consisted of memorizing selected verses from the Al-Qur'an outside juz 30, memorizing juz 30, mufrodat, and mahfudzat of Arabic, English, and Javanese, daily worship practices decided by the tarjih council.

Based on the interview results, the planning to strengthen character education based on golden habits at SMP Muhammadiyah 1 Depok Yogyakarta was carried out by forming a development team under the leadership of the vice principal of student affairs known as the PPK team. After the development team was formed, the team formulated and designed various activities by integrating the five character values as golden habits at SMP Muhammadiyah 1 Depok Yogyakarta. The PPK team's formulation and design of various activities by integrating the five character values resulted in a book entitled Golden Habits SMP Muhammadiyah 1 Depok Yogyakarta; ISMUBARIS Based on Character Education as a guide in strengthening character education. 


\section{Implementation of Strengthening Character Education Based on Golden Habits at SMP Muhammadiyah 1 Depok Yogyakarta}

Based on the results, it is not enough to explain only in shaping students who have character. It is $\mathrm{n}$ e cessary to g et habituation to doing something good, hoping that students will have good character. The orientation of SMP Muhammadiyah 1 Depok Yogyakarta based on the school's vision, mission, and goals are to form noble moral students to create students' identities with Islamic and Muhammadiyah characteristics. To realize the school orientation, SMP Muhammadiyah 1 Depok Yogyakarta has implemented a movement to strengthen character education based on gold refraction or golden habits with the guid ebook "Golden Habits SMP Muhammadiyah 1 Depok Yogyakarta; ISMUBARIS Based on Character Education”.

The movement to strengthen character education at SMP Muhammadiyah 1 Depok Yogyakarta has been implemented since 2010 as conveyed by $\mathrm{Mr}$. Abdullah Mukti as the Principal of the School. In 2016, with the existence of a cha racter education st $r$ engthening $p$ rogram by the government, SMP Muhammadiyah 1 Depok Yogyakarta implementing strengthening character educatio $\mathrm{n}$ was carried out $\mathrm{m}$ o re clearly a nd more comprehensively. They volunteered and were appointed by the government as a pilot school in character education, strengthened by Presidential Regulation No. 87 of 2017 concerning the Movement of Strengthening Character Education.

The movement to strengthen character education based on golden habits was carried out through ISMUBARIS activities. They were tahfidz (selected verses of the Quran beyond juz 30, memorization of choice and compulsory juz 30), mufrodat and mahfudzat in Arabic, English, and Javanese, the practice of daily worship which was decided by the tarjih assembly. ISMUBARIS activities at SMP Muhammadiyah 1 Depok Yogyakarta were carried out every school day, Monday-Friday, based on Permendikbud No. 23 of 2017 about school days. The details of the activities and schedule for implementing the ISMUBARIS program at SMP Muhammadiyah 1 Depok Yogyakarta based on the results of the research conducted. First, it is the Material of Elective Letters. The implementation of the movement to strengthen character education through elective letters begins with the activity of completing reading the Qur'an for one semester or iqra' for grade VII at school. This activity was every Monday-Friday at 15.00-16.00 WIB or after Asr prayer. There was a unique thing in the implementation of this activity. The iqra' activity or completing reading the Al-Qur'an determined the seventh-grade students to increase their grade. If students had not finished reading the AlQur'an during grade VII, a maximum of one month before the class promotion exam, these students were not entitled to advance to class VIII even though all the subjects' scores are complete. It was conveyed emphatically by Mr. Mukti 
as the Head of SMP Muhammadiyah 1 Depok Yogyakarta. The activity of iqra' or completing reading the Qur'an was a determinant for grade VII students to increase their grade. If students had not finished reading the Al-Qur'an during class VII, a maximum of one month before the class promotion exam, they are not entitled to advance to class VIII even though the scores in each subject are all complete.

Strengthening character education through memorizing selected letters was carried out because the Qur'an is the main and first source of Islamic teachings. Apart fr om being read, the Al-Qur'an also needs to be memorized because memorizing the Qur'an can maintain the authenticity and purity of the Qur'an itself. Referring to the interview data, the activity of memorizing the Qur'an from selected letter material at SMP Muhammadiyah 1 Depok Yogyakarta was held on Thursday for 15 minutes after the break ends; it was 12.45-13.00 WIB.

Based on the results of empirical observations, the implementation mechanism was that the teacher checked readiness and asked students to open the Qur'an, juz amma, or the golden habits book, then guided students to read the Qur'an together. After finishing reading the Qur'an together, the teacher called 1 to 4 students randomly and took turns to the front to memorize the letters that have been read together. The teacher recorded them on the student's rote evaluation sheet for students who had come forward to memorize storage.

Tahfidz activity is carried out with the hope that besides being fond of reading and memorizing the Qur'an, students can use the Al-Qur'an as a guide in their life. Because the Qur'an contains lessons and values, both divine and worship values, this activity is proof that students at SMP Muhammadiyah 1 Depok Yogyakarta have succeeded in completing reading the Qur'an for one semester. This activity is also proof of the students' faith and devotion to Allah because every day except Monday and Friday, they carry out tahfidz activities.

Based on the analysis of documented data, in determining the letter of choice, the school had the basis for establishing it as the implementation of the movement to strengthen character education. For example, QS Luqman verses 12-19 for grade VII were determined because there were orders always to be grateful for Allah's blessings, shirk prohibition, respect for parents, establish prayers, and amar ma'ruf nahi munkar, and always have humility. Thus, religious characteristics and integrity emerged in students.

In Surah Ali-Imran verses 102-104, there is an order to remain istiqamah in devotion to Allah. In this verse, it is also instructed to always unite in upholding Allah's religion and become a group that always acts as ma'ruf nahi munkar so that the characteristics of integrity and cooperation emerge.

Meanwhile, the selection of letters for class VIII, namely QS Al-Baqarah verses 255-257, illustrates Allah's power that cannot be matched by His creatures. 
Allah al ways monitors every human movement, and there is a prohibition against committing kufr to Allah so that religious and integrity characteristics emerge. In QS Al-Mukminun, verses 1-11 describe the personality of a true believer. It is consistently maintaining a relationship with God through worship and always maintaining relationships with others through a noble personality. A noble social personality is illustrated through the nature of sharing, maintaining genitals, and keeping promises, so that religious, nationalist, cooperation, and integrity characteristics emerge.

The sele ction of letters for class IX was QS Ar-Rahman verses 1-13. It describes the love of Allah in creating humans. It is also illustrated that all of Allah's creatures always prostrate to Him. So the commandment that depends on it is always to be grateful for His blessings so that the characteristics that always love fellow creatures of Allah emerge. In Surah Ali-Imran, verses 190-194 describe Allah's creation in the form of heaven and earth and the alternation of day and night. Also, it explains the characteristics of a person who is intelligent, and contains the prayers and hopes of a servant to Allah, so that through this verse, a personal characteristic of integrity is built.

Second, it is compulsory and elective juz 30 material. The activity of memorizing Al-Qur'an or the activity of tahfidz material juz 30 options at SMP Muhammadiyah 1 Depok Yogyakarta was held on Tuesday-Thursday for 20-30 minutes after performing the Duha prayer in the congregation; it was 07.00 07.30 WIB. Memorizing the Qur'an or the compulsory tahfidz of juz 30 material as a movement to strengthen character education at SMP Muhammadiyah 1 Depok Yogyakarta was held on Monday for 15 minutes after the break ends; it was $12.45-13.00$ WIB. This activity aimed to maintain the authenticity and purity of the Qur'an itself. It is because the Qur'an is the main and first source of Islamic teachings.

Based on the results of empirical observations, the implementation mechanism was that the teacher checked readiness and asked students to open the Qur'an, juz amma, or the golden habits book, then guided them to read the Qur'an together. After finishing reading the Qur'an together, the teacher called 1 to 4 students randomly and took a turn to the front to memorize the letters that have been read together. The teacher recorded them on the student's rote evaluation sheet for students who had come forward to memorize storage.

This tahfidz activity is carried out with the hope that besides being fond of reading and memorizing the Qur'an, students can use the Al-Qur'an as a guide in their lives. It is because the Qur'an contains lessons and values, both divine and worship values. This activity is proof that students at SMP Muhammadiyah 1 Depok Yogyakarta have succeeded in completing reading the Qur'an for one 
semester. This activity also proves the students' faith and devotion to Allah because every day, except Monday and Friday, they carry out tahfidz activities.

Third, mufradat, mahfudzat, and wise word. The next strengthening of golden habits-based character education is carried out through some activities. (1) Mufr adat. The implementation of strengthening character education based on golden habits through integrated mufradat activities in ISMUBARIS activities was carried out by 40 words for each grade VII-IX, 20 verbs for each grade VII-IX, and adjectives for 20 words in each grade VII-IX. (2) Mahfudzat. The implementation of strengthening character education based on golden habits through integrated mahfudzat activities in ISMUBARIS activities was carried out with details of as many as 20 Arabic proverbs for grade VII, as many as 20 Arabic proverbs for grade VIII, and as many as 20 Arabic proverbs for grade IX. However, the results of the analysis of mahfudzat contained in the Golden Habits manual showed that the implementation of the character education strengthening movement still has not integrated the five character values contained in Presidential Decree No. 87 of 2017.

It can be seen from the integrated character values. They are the integrity and independence character, while the religious, nationalist, and cooperation characters have not been integrated for class VII. Meanwhile, the integrated character values for class VII, namely the character of integrity, cooperation, and inde $\mathrm{p}$ endence, $\mathrm{h}$ ave not been integrated for religious and nationalist characters. Class IX's integrated character values are integrity, cooperation, and independence, while those for religious and nationalist characters have not been integrated.

Suppose SMP Muhammadiyah 1 Depok Yogyakarta would like to carry out a movement to strengthen character education through mahfudzat optimally, comprehensively, and live in the students' lives. Then, the school must integrate the five character values contained in Presidential Decree No. 87 of 2017 into every golden habit that exists in schools. (3) Wise word. The implementation of strengthening character education based on golden habits through integrated wise words in ISMUBARIS activities was carried out with 20 Arabic proverbs for grade VII, as many as 20 Arabic proverbs for grade VIII, as 20 Arabic proverbs for grade IX. The documentation data analysis results in the Golden Habits book showed that SMP Muhammadiyah 1 Depok Yogyakarta had implemented a movement to strengthen character education based on golden habits through word-wis e activities at eve ry level, namely grades VII, VIII, and IX. In its implementation, the school had integrated the five character values contained in Presidential Decree No. 87 of 2017. It can be seen from the integrated character values, namely religious, nationalist, cooperation, integrity, and independence. 
On Tuesday, for 15 minutes after the break ends, it was 12.45-13.00 WIB at SMP Muhammadiyah 1 Depok Yogyakarta in each class.

Fourth, Daily Worship Practices. Based on the results of interviews and empirical observations, strengthening character education through the practice of daily worship at SMP Muh a mmadiyah 1 Depok Yogyakarta begins with equipping students with compulsory prayer and funeral prayers. It is intended that students can carry out daily worship practices properly and correctly. This debriefing activity is carried out through reading the compulsory prayers and the corpse, which is held on Tuesday for 15 minutes after the break ends, which is 12.45-13.00 WIB.

After being equipped with the theory, students needed the means to put the theory into practice. As a form of actualization of the theory that has been obtained, the strengthening of character education through the practice of daily worship activities was carried out through Duha prayers, Zuhur, and Asr prayers in congregation based on a predetermined schedule and followed by dzikir and prayer together. The congregational prayer activity aimed to train and accustom students to practice daily worship as servants who always carry out Allah's orders and stay away from all His prohibitions. Therefore, it is expected that the students become devout Muslims to carry out religious orders in the future. They also have the responsibility and a good attitude in their daily lives.

Based on empirical observations and documentation results, Duha prayer activities were at $06.45 \mathrm{WIB}$, Zuhur prayer was at $12.00 \mathrm{WIB}$, and Asr prayer was at 15.00 WIB. They were carried out by the entire school academic community with supervision, guidance, and led directly by the school. It was clear evidence that SMP Muhammadiyah 1 Depok Yogyakarta had a culture of strengthening character education for all school parties. It was carried out based on a determined schedule with the aim that each activity can run in a conducive, orderly, and solemn manner.

Duha prayer is the sunnah prayer in the morning with a minimum number of 2 cycles. It was routinely carried out every day, actively entering school. Before performing the Duha prayer, the activity began with tadarus to await all parties who will perform the Duha prayer. After all, parties were ready; the Duha prayer activities could be carried out and accepted by the teacher based on a predetermined schedule. Meanwhile, the implementation of the Zuhur and Asr prayers was also attended by all school members. They were students, teachers, school principals, and educational staff. The school used various methods to motivate students to carry out this activity. One of which was through the example of the teacher. The facilities and infrastructure in the Mushalla of SMP Muhammadiyah 1 Depok Yogyakarta were sufficient to accommodate all madrasa citizens in carrying out 
congregational prayer activities. As for Fridays, the midday prayer activities were replaced with Friday worship activities at schools.

Through this activity, it is hoped that all parties will get used to praying five times a day in the congregation because, as it is known that prayer is a pillar of religion and if praying in the congregation, the reward will be multiplied by 27 times. Also, performing prayers can prevent heinous and evil actions, as Allah says in QS Al-Ankabut verse 45. Therefore, prayer must be accustomed to as early as possible, including congregational prayer. It will become a good habit because it is embedded in every student. So, they have a sense of responsibility for religious teachings and have a solid religious attitude in everyday life.

Along wi th the change in education practitioners' mindset at SMP Muhammadiyah 1 Depok Yogyakarta, Islamic values and kemuhammadiyahan occur solid internalization, namely having a strong Islamic character and becoming a culture student, schools and in social life, the school organizes the live-in program. In developmental psychology, activities like this are very suitable for students at the primary and secondary education levels because through habituation and good example, it can be used as uswah to form a character in accordance with Islamic teachings. After students are equipped with various kinds of knowledge, a means to practice them is needed.

It is the nature of students through the integration of character values in ISMUBARIS activities. According to Hasan Langgulung, the Arabic word fitrah has the meaning of being created by Allah, in the sense that Allah has given humans good potential. Therefore, even though he is not educated, man will automatically conform to religion's teachings because he has been created according to it, unless he is educated otherwise, that is, to be educated to deny religion..$^{22}$

It explains that human nature tends to goodness, truth, beauty, glory, and holiness. Concerning the movement to strengthen character education based on golden habits, strengthening character education will be even stronger when students grow according to their nature. Students who know their potential well and are facilitated to be developed will become a performance character that is easy to develop in everyday life.

\section{Evaluation of Strengthening Character Education Based on Golden Habits at SMP Muhammadiyah 1 Depok Yogyakarta}

Based on the results of the conducted research, the process of evaluating the program to strengthen character education based on golden habits at SMP Muhammadiyah 1 Depok Yogyakarta was carried out by adjusting the indicators of

\footnotetext{
${ }^{22}$ Hasan Langgulung, Pendidikan Dan Peradaban Islam (Jakarta: Pustaka Al-Husna, 1985),
} 215. 
character education strengthening programs (religious, nationalist, cooperation, independence, and integrity) and attitude assessment indicators (very good, good, not sure, quite good and bad) as contained in the book Golden Habits SMP Muhammadiyah 1 Depok Yogyakarta; ISMUBARIS Based on Character Education. This evaluation sheet included all the activities in ISMUBARIS that the teacher did at a predetermined time.

For tahfidz activities, the teacher also carried out a tahfidz evaluation sheet on the schedule for implementing the activity. For example, students memorized QS An-Naziat 1-6, then the amount of this deposit was recorded by the teacher on the tahfidz evaluation sheet. The book's evaluation is Golden Habits SMP Muhammadiyah 1 Depok Yogyakarta; ISMUBARIS Based on Character Education for tahfidz activities. There were three scales of scoring technique in the evaluation sheet. They were not fluent, quite fluent, and fluent. Besides, teachers also evaluated students' behavior. The report of students' character behavior observations and assessment through scoring is shown in the following table.

Table 1. Assessments Through Scoring

\begin{tabular}{|c|c|c|c|c|c|c|c|c|c|c|c|}
\hline \multirow{2}{*}{ No. } & \multirow{2}{*}{$\begin{array}{c}\text { Student } \\
\text { Code }\end{array}$} & \multicolumn{2}{|c|}{ Religious } & \multicolumn{2}{|c|}{ Nationalist } & \multicolumn{2}{|c|}{ Cooperation } & \multicolumn{2}{|c|}{ Independence } & \multicolumn{2}{|c|}{ Integrity } \\
\hline & & Score & Score & Score & Score & Score & Score & Score & Score & Score & Score \\
\hline 1 & Student 1 & 36 & 72 & 34 & 68 & 44 & 88 & 42 & 84 & 30 & 60 \\
\hline 2 & Student 2 & 46 & 92 & 48 & 96 & 46 & 92 & 47 & 94 & 36 & 72 \\
\hline 3 & Student 3 & 44 & 88 & 40 & 80 & 42 & 84 & 42 & 84 & 34 & 68 \\
\hline 4 & Student 4 & 40 & 80 & 34 & 68 & 40 & 80 & 44 & 88 & 34 & 68 \\
\hline 5 & Student 5 & 44 & 88 & 34 & 68 & 48 & 96 & 44 & 88 & 30 & 60 \\
\hline 6 & Student 6 & 40 & 80 & 28 & 56 & 34 & 68 & 44 & 88 & 38 & 76 \\
\hline 7 & Student 7 & 46 & 92 & 34 & 68 & 48 & 96 & 44 & 88 & 38 & 76 \\
\hline 8 & Student 8 & 44 & 88 & 38 & 76 & 38 & 76 & 44 & 88 & 30 & 60 \\
\hline 9 & Student 9 & 40 & 80 & 31 & 62 & 40 & 80 & 44 & 88 & 39 & 78 \\
\hline 10 & Student 10 & 42 & 84 & 32 & 64 & 48 & 96 & 44 & 88 & 38 & 76 \\
\hline 11 & Student 11 & 40 & 80 & 36 & 72 & 48 & 96 & 42 & 84 & 34 & 68 \\
\hline 12 & Student 12 & 42 & 84 & 44 & 88 & 46 & 92 & 44 & 88 & 34 & 68 \\
\hline 13 & Student 13 & 42 & 84 & 28 & 56 & 48 & 96 & 44 & 88 & 38 & 76 \\
\hline 14 & Student 14 & 42 & 84 & 36 & 72 & 40 & 80 & 44 & 88 & 30 & 60 \\
\hline 15 & Student 15 & 44 & 88 & 36 & 72 & 44 & 88 & 44 & 88 & 36 & 72 \\
\hline 16 & Student 16 & 46 & 92 & 46 & 92 & 46 & 92 & 47 & 94 & 34 & 68 \\
\hline 17 & Student 17 & 46 & 92 & 32 & 64 & 44 & 88 & 42 & 84 & 34 & 68 \\
\hline 18 & Student 18 & 46 & 92 & 40 & 80 & 46 & 92 & 44 & 88 & 38 & 76 \\
\hline 19 & Student 19 & 46 & 92 & 40 & 80 & 42 & 84 & 44 & 88 & 38 & 76 \\
\hline 20 & Student 20 & 44 & 88 & 34 & 68 & 44 & 88 & 44 & 88 & 34 & 68 \\
\hline
\end{tabular}


Cendekia Vol. 18 No 2, Juli - Desember 2020205

\begin{tabular}{|l|l|l|l|l|l|l|l|l|l|l|l|}
\hline 21 & Student 21 & 40 & 80 & 42 & 84 & 40 & 80 & 40 & 80 & 33 & 66 \\
\hline 22 & Student 22 & 46 & 92 & 38 & 76 & 42 & 84 & 46 & 92 & 34 & 68 \\
\hline 23 & Student 23 & 44 & 88 & 42 & 84 & 42 & 84 & 44 & 88 & 47 & 94 \\
\hline 24 & Student 24 & 40 & 80 & 38 & 76 & 38 & 76 & 46 & 92 & 32 & 64 \\
\hline 25 & Student 25 & 44 & 88 & 34 & 68 & 44 & 88 & 42 & 84 & 38 & 76 \\
\hline
\end{tabular}

Source: Documentation of PPK Values at SMP Muhammadiyah 1 Depok Yogyakarta

The cognitive and affective assessments in the program of strengthening character education based on golden habits referred to the five character values and using the assessment guidelines co ntained in the book Golden Habits SMP Muhammadiyah 1 Depok Yogyakarta; ISMUBARIS Based on Character Education. However, the assessment could not be done one by one. It only assessed the most prominent character of students, both positive and negative. It contained a separate sheet regarding the attitude assessment observation sheet.

Based on the observations and documentation results, it showed that there were also spontaneous evaluations carried out by the teacher. For example, for students who did not carry the golden habits book, they were asked to stand in front and recited one of the letters determined by the teacher collectively. For those who were unable to pronounce it, other students who did not stand forward were asked to ask questions about previous learning material. If he could not answer it, the teacher wrote those standing in front and then allowed him to go back. It was inversely proportional to what was conveyed by Mr. Abidin Fuadi as the assistant principal of curriculum and Ismuba teacher on February 25, 2019, at $11.30 \mathrm{WIB}$ in the administration room at SMP Muhammadiyah 1 Depok Yogyakarta. He said that punishment was not justified by physical violence. For students who violate, for example, if he had not memorized the verses of the Qur'an well, then he had to memorize them again until it ran smoothly.

The data analysis above showed a gap b etween Mr. Abidin Fuadi's expectations and the facts in the field, as seen in the empirical observational data. Based on the researchers' perspective, punishment is one form of approach in strengthening character education to affect students. Punishment in supporting character education is a form of giving unpleasant actions to students who made a violation. It is an educational punishment. It is not physical violence. In addition to applying punishment, SMP Muhammadiyah 1 Depok Yogyakarta also provides rewards to students who achieved. It is based on the results of an interview with Mr. Abidin Fuadi, who said that the school gives rewards to students at the end of each semester. The form of reward is adjusted to the school budget.

The results of processed interview data showed that the evaluation of strengthening character education based on golden habits was also done through 
the analysis of program implementation. They observed student behavior changes through work meetings, observing reports of student character behavior, and scoring. When a student did a violation, he would get punishment and points according to the type of violation committed. For example, for students who were late reporting to the picket officer on duty, then the name of the student who was late to be recorded in the picket book. They were asked why they were late and were given a penalty for performing prayers.

It should be noted that for the administration of punishment, it was the full authority of the picket officer on that day. There are some follow-ups to the evaluation process of strengthening character education based on golden habits. They are various reforms of character education strengthening programs, maximizing various support capacities, and building cohesiveness among personnel to correct previous character education strengthening programs' shortcomings. This follow-up is carried out through work meetings, committee meetings, coordination meetings, and year-end meetings.

\section{CONCLUSION}

The pattern of strengthening character education based on golden habits at SMP Muhammadiyah 1 Depok Yogyakarta is reflected in ISMUBARIS activities. It involves aspects of planning, implementation, and evaluation. The planning to strengthen character education based on golden habits is carried out with a pattern of socialization to education practitioners, translation into the vision, mission, and goals of the school, designing and formulating activities to strengthen character education through habituation by integrating the character values contained in Presidential Decree No. 87 of 2017. Meanwhile, strengthening character education based on golden habits is carried out with a pattern of memorizing selected Qur'anic verses outside juz 30, memorizing optional and compulsory juz 30, mufrodat, and mahfudzat of Arabic, English, and Javanese, daily worship practices decided by the tarjih council. Character education strengthening activities are held on Monday-Thursday at 12.45-3.00 WIB.

Meanwhile, the evaluation of strengthening character education based on golden habits is carried out by an evaluation sheet pattern through the three-scale scoring technique, spontaneously, analysis of program implementation through work meetings, observing changes in student behavior, observing reports of student character behavior and scoring. The follow-up of the evaluation process of strengthening character education based on golden habits is carried out through work meetings, committee meetings, coordination meetings, year-end meetings. It is to carry out various program improvements, maximize various 
Cendekia Vol. 18 No 2, Juli - Desember 2020207

support capacities, and build the compactness among personnel to fix the shortcomings of previous character education strengthening programs. 


\section{REFERENCES}

Agama, Departemen. Al-Hikmah; Al-Quran Dan Terjemahannya. Bandung: Diponegoro, 2008.

Agus Wibowo. Manajemen Pendidikan Karakter Di Sekolah. Yogyakarta: Pustaka Pelajar, 2013.

Alfiasari, Alfiasari, Dwi Hastuti, and Sarwititi Sarwoprasodjo. "An Integration of Family and School on Strengthening the Character of Teenager in Indonesia: It's a Must." Journal of Child Development Studies 1, no. 01 (2016): 13. https://doi.org/10.29244/jcds.1.01.13-26.

Dahliyana, Asep. "Penguatan Pendidikan Karakter Melalui Kegiatan Ekstrakurikuler Di Sekolah.” Sosio Religi: Jurnal Kajian Pendidikan Umum 15, no. 1 (2017).

Fachruddin, Sutiyana, S Sos, M I Kom, Rivi Handayani, M Si, La Ode Sahidin, S Pd, and M Hum. "Communication Model Based-Character Strengthening Through Language Politeness As Prevention Of Bullying Toward Junior High School ( Case Study At Smpn 20 Kota Kendari )” 7, no. 5 (2017): 68-75. https://doi.org/10.9790/7388-0705066875.

Firman, Arham Junaidi. "Menyoal Akses Pendidikan Bagi Kelompok Marginal

Dalam Mewujudkan Kesetaraan Dalam Pendidikan." In PROSIDING SEMINAR NASIONAL "TELLU CAPPA” (Kontribusi Untuk Pendidikan, Genetika Emas Indonesia), 109-16. Makassar: Badan Penerbit Universitas Negeri Makassar, 2017.

__. "Paradigma Hasan Langgulung Tentang Konsep Fitrah Dalam Pendidikan Islam." Jurnal Uhamka 8, no. 2 (2017): 123-43.

Hasan, Yetri, and Rijal Firdaos. "Penguatan Pendidikan Karakter Berbasis Masyarakat Pada Sekolah Menengah Pertama Negeri (SMPN) Di Kabupaten Tulang Bawang Provinsi Lampung." Al-Tadzkiyyah: Jurnal Pendidikan Islam 8, no. 2 (2017): 267. https://doi.org/10.24042/atjpi.v8i2.2131.

Hidayat, Nur. Pendidikan Karakter Di Pesantren; Model Keteladanan Dan Pembiasaan. Yogyakarta: Calpulis, 2018. 
Hilmi, Alfan. "Hari Pendidikan, KPAI: 84 Persen Student Alami Kekerasan Di Sekolah,” 2018. https://nasional.tempo.co/read/1084922/haripendidikan-kpai-84-persen-Student-alami-kekerasan-di-sekolah.

Komara, Endang. "Penguatan Pendidikan Karakter Dan Pembelajaran Abad 21.” SIPATAHOENAN: South-East Asian Journal for Youth, Sports \& Health Education 4, no. 1 (2018): 17-26. www.journals.mindamas.com/ index.php/sipatahoenan.

Langgulung, Hasan. Pendidikan Dan Peradaban Islam. Jakarta: Pustaka AlHusna, 1985.

Maisaro, Atik. "Manajemen Program Penguatan Pendidikan Karakter Di Sekolah Dasar." JAMP: Jurnal Administrasi Dan Manajemen Pendidikan 1, no. 3 (2018): 302-12.

Makmun, H.A. Rodli. "PEMBENTUKAN KARAKTER BERBASIS PENDIDIKAN PESANTREN: Studi Di Pondok Pesantren Tradisional Dan Modern Di Kabupaten Ponorogo." Cendekia: Jurnal Kependidikan Dan Kemasyarakatan 12, no. 2 (2016): 211. https://doi.org/10.21154/cendekia. v12i2.226.

Muhammad Nabil Kazhim. Sukses Mendidik Anak Tanpa Kekerasan. Solo: Samudera, 2011.

Nata, Abuddin. Filsafat Pendidikan Islam. Jakarta: Logos Wacana Ilmu, 1997.

Rachmadyanti, Putri. "Rachmadyanti, P. (2017). Penguatan Pendidikan Karakter Bagi Student Sekolah Dasar Melalui Kearifan Lokal. Jurnal Pendidikan Sekolah Dasar, 3(2), 201-214.” 3, no. 2 (2017): 201-14.

RI, Presiden. Peraturan Presiden RI No. 87 Tahun 2017 Tentang Penguatan Pendidikan Karakter. Jakarta: Presiden RI, 2017.

Salsabilah. "PENDIDIKAN KARAKTER ISLAMI BERBASIS NILAI-NILAI KEARIFAN LOKAL (Penelitian Di SDN 12 Ciseureuh Kahuripan Pajajaran Purwakarta)." Cendekia 17, no. 2 (2019): 269-84.

Syafri, Ulil Amri. Pendidikan Karakter Berbasis Al-Qur'an. Jakarta: Rajawali Pers, 2012.

Werdiningsih, Wilis. "Pengembangan Nilai Karakter Student Dalam Pendidikan Agama Islam Dan Budi Pekerti Pada Kurikulum 2013.” Cendekia: Journal 
210 Arham Junaidi Firman dkk, Strengthening Character Education

of Education and Society 15, no. 2 (2018): 283. https://doi.org/10.21154/ cendekia.v15i2.1123.

Widodo, Hendro. "Penguatan Pendidikan Karakter Di Sd Muhammadiyah Macanan Sleman Yogyakarta." Lentera Pendidikan 22, no. 1 (2019): 40-51. 